\title{
Development of Bottle Gourd Lines Resistant to Zucchini Yellow Mosaic Virus Using Ethyl Methanesulfonate Mutagenesis
}

Asma Mohammed Saeed Al-Kubati, Baoshan Kang, and Liming Liu Zhengzhou Fruit Research Institute, Chinese Academy of Agricultural Sciences (CAAS), Zhengzhou 450009, Henan, China

\section{Aqleem Abbas}

State Key Laboratory of Agriculture Microbiology and Hubei Key Laboratory of Plant Pathology, Huazhong Agricultural University, Wuhan 430070, Hubei, China

\section{Qinsheng Gu \\ Zhengzhou Fruit Research Institute, Chinese Academy of Agricultural Sciences (CAAS), Zhengzhou 450009, Henan, China}

Additional index words. ethyl methanesulfonate, Lagenaria siceraria, mutagenesis, resistant, zucchini yellow mosaic virus

Abstract. Zucchini yellow mosaic virus (ZYMV) causes serious damage to cucurbit crops worldwide and can be spread by aphids, by mechanical injury, and in seeds. With the popularization of cucurbit grafting, the use of susceptible rootstock has increased the risk of ZYMV infection in cucurbit crops. In China, the bottle gourd (Lagenaria siceraria) is a widely used rootstock in grafted watermelon production. However, few resistant bottle gourds are available commercially. This study developed bottle gourd lines resistant to ZYMV using ethyl methanesulfonate (EMS) mutagenesis. A new mutated bottle gourd population $\left(M_{1}\right)$ was generated by treating seeds with EMS. Diverse phenotypes were observed in the seedlings, flowers, and fruit of $M_{2}$ plants, some of which are of potential commercial interest, such as dwarfing and different fruit shapes. Based on the $M_{2}$ phenotypes, $106 M_{3}$ lines were selected and screened for resistance to ZYMV by mechanical inoculation and agroinfiltration. Nine $M_{3}$ lines were resistant to $Z Y M V$ during three tests. One inbred $M_{4}$ line (177-8) was developed and showed stable resistance and no virus when tested using a doubleantibody sandwich enzyme-linked immunosorbent assay (DAS-ELISA) and polymerase chain reaction. These resistant lines are promising materials for developing watermelon rootstock and exploring resistance genes as new ZYMV-resistant resources. EMS induction could be a practical strategy for creating resistant cucurbit crops.

Zucchini yellow mosaic virus (ZYMV), a member of the genus Potyvirus in the family Potyviridae, infects cucurbits worldwide. Plants infected with ZYMV develop blistering and malformed leaves. The disease can reduce fruit yield and quality, thereby destroying the crop (Desbiez and Lecoq, 1997; Nagendran et al., 2017). It can be transmitted mechanically or by aphids using a nonpersistent mode,

Received for publication 8 Apr. 2021. Accepted for publication 17 May 2021

Published online 23 June 2021

This work was supported by the National Natural Science Foundation of China (grant no. 31701942), the Central Public-interest Scientific Institution Basal Research Fund (grant no. 1610192021401), and China Agriculture Research System of MOF and MARA (CARS-25).

Q.G. and B.K. are the corresponding authors. E-mail: guqinsheng@caas.cn or kangbaoshan@ caas.cn.

This is an open access article distributed under the CC BY-NC-ND license (https://creativecommons. org/licenses/by-nc-nd/4.0/) as well as by seeds (Desbiez and Lecoq, 1997 ; Simmons et al., 2013). Considerable efforts have been devoted to controlling ZYMV disease, including cross-protection (Gal-On, 2000; Wang et al., 1991), using chemicals to control vectors, host resistance (Guner et al., 2018), and biological control. However, ZYMV is prevalent worldwide. An economical and efficient way of solving this problem is breeding resistant varieties. However, the lack of resistant material limits progress in breeding resistance.

Grafting technology is increasingly being used in vegetable production to allow continuous cropping (Colla et al., 2010). For cucurbits, the bottle gourd (Lagenaria siceraria) is an essential rootstock used to improve the disease resistance of grafted plants (also known as a scion), especially watermelon or melon (Gaion et al., 2017). However, the scion might be incompatible or potentially infected with seed-borne viruses during the grafting process. Natural infection of the bottle gourd by ZYMV has been reported in many countries (Fidan et al., 2016; Svoboda et al., 2013). Susceptible rootstock increases the risk of yield loss of watermelon and melon production. With the popularization of watermelon and melon grafting, the demand for disease-resistant rootstock has increased markedly. However, commercial bottle gourd cultivars are generally susceptible to viral diseases (Ling et al., 2013). Compared with conventional breeding, mutation breeding creates variability in a crop species and shortens the time taken to develop cultivars. EMS is a mutagenic agent that causes random point mutations at high density and can cause allelic mutations throughout the genome of any species (Okagaki et al., 1991). EMS mutagenesis to generate resistance to potyviruses has been reported for Arabidopsis (Duprat et al., 2002; Lellis et al., 2002). Several Cucurbitaceae species have been subject to EMS mutagenesis, including Cucumis melo (Dahmani-Mardas et al., 2010; González et al., 2011), Cucumis sativus (Boualem et al., 2014), and Cucurbita pepo (Vicente-Dólera et al., 2014). Using EMS to induce virus resistance in the bottle gourd has not been reported. We developed bottle gourd lines resistant to ZYMV using an EMS-mutagenized population to produce novel material for breeding resistant cultivars or rootstock.

\section{Materials and Methods}

Derivation of $M_{3}$ bottle gourd lines. The seeds of wild-type bottle gourd 'Anshenghulu', an inbred line that has been self-pollinated for many generations, were provided by Ansheng Seed Company (Anhui Province, China). This variety is widely used as rootstock to graft watermelon in China because of its high affinity. Unfortunately, it is susceptible to many viruses, including ZYMV.

Approximately 11,000 Anshenghulu seeds were cracked and soaked in $\approx 55^{\circ} \mathrm{C}$ water for $4 \mathrm{~h}$. Subsequently, the seeds were divided into two equal parts and treated with $1.2 \%$ and $1.5 \%(\mathrm{v} / \mathrm{v})$ EMS (Aladdin, Shanghai), respectively, at $25 \pm 2{ }^{\circ} \mathrm{C}$ for $8 \mathrm{~h}$, which we previously determined was the optimal semi-lethal condition (Kang et al., 2017). After treatment, the $M_{1}$ seeds were sown in a field. At flowering, the plants self-pollinated; ultimately, 364 $\mathrm{M}_{2}$ families were harvested. Approximately 10 to 20 seeds from each $\mathrm{M}_{2}$ family were selected, grown, and self-pollinated. Finally, $2444 \mathrm{M}_{3}$ lines from $303 \mathrm{M}_{2}$ families were obtained and used to screen for resistance to ZYMV.

Phenotyping $\mathrm{M}_{2}$ individuals. During growth of the $\mathrm{M}_{2}$ plants, phenotypic variation in seedlings, leaves, flowers, and fruit was evaluated. Viral infections caused by aphids and seeds were observed in $\mathrm{M}_{2}$ plants in the field. At the flowering stage, we also recorded the $\mathrm{M}_{2}$ families with no viral symptoms, such as mosaic, mottle, yellowing, and others, which could indicate resistance to the virus.

Inoculum preparation and inoculation. The ZYMV isolate (ZYMV-CH87) originated from a naturally infected melon and was stored at $-80^{\circ} \mathrm{C}$. Before inoculation, the virus isolate was maintained on susceptible zucchini (Cucurbita pepo L.) cultivars. For 
mechanical inoculation, an inoculum was prepared by homogenizing leaves of infected zucchini in $0.01 \mathrm{M}$ phosphate buffer $(\mathrm{pH} 7.2$; $1: 10 \mathrm{w} / \mathrm{v})$ using a mortar and pestle. Seedlings were inoculated at the one true leaf stage by mechanically injuring seedling cotyledons using carborundum powder and then gently rubbing the inoculum by hand to ensure that they were coated with the homogenate. The inoculum was kept on ice until inoculation was complete. After inoculation, the carborundum was rinsed from the leaves.

Recently, our group (Liu et al., 2020) constructed an enhanced green fluorescent protein (eGFP)-carrying infectious clone of ZYMVCH87 (named pXT1-ZYMV-eGFP) and used it to inoculate plants by agroinfiltration. Agrobacterium tumefaciens strain GV3101 harboring pXT1-ZYMV-eGFP was cultured in lysogeny broth medium containing $100 \mathrm{mg} / \mathrm{L}$ kanamycin at $28^{\circ} \mathrm{C}$ overnight. Then, $1 \mathrm{~mL}$ of bacterial culture was added to $10 \mathrm{~mL}$ of lysogeny broth medium containing $100 \mathrm{mg} / \mathrm{L}$ kanamycin and $100 \mu \mathrm{M}$ acetosyringone and further incubated at $28^{\circ} \mathrm{C}$ until the optical density at $600 \mathrm{~nm}$ reached 1.5. The A. tumefaciens cultures were centrifuged; then, the cells were resuspended in $10 \mathrm{~mL}$ of infiltration medium (10 mM MES, $10 \mathrm{~mm} \mathrm{MgCl}_{2}$, and $100 \mathrm{~mm}$ acetosyringone) and incubated at room temperature for 2 to $12 \mathrm{~h}$. Then, the two cotyledons were infiltrated with $A$. tumefaciens suspension at the one true leaf stage.

Mechanical inoculation was used during primary screening and retesting. The method of agroinfiltration with pXT1-ZYMV-eGFP was used during the third test.

Planting and screening. The plants were grown individually in 13-cm-diameter, 11$\mathrm{cm}$-high plastic pots. During primary screening, all plants were maintained at 20 to $35^{\circ} \mathrm{C}$ for $30 \mathrm{~d}$ in insect-proof cages to prevent contamination by other viruses. Retesting and a third test were performed after the last screening to verify the resistant lines in growth chambers under an 8 -h dark $\left(20^{\circ} \mathrm{C}\right) /$ 16 -h light $\left(30^{\circ} \mathrm{C}\right)$ cycle. For all tests, inoculated wild-type was used as a positive control and healthy wild-type was used as a negative control. Viral symptoms were evaluated $30 \mathrm{~d}$ postinoculation (dpi), along with positive and negative controls. We used one replicate per line during the primary screening, three replicates each during the retest and third test, and three replicates for positive and negative controls during all tests. The presence of ZYMV in plants was assessed using a DAS-ELISA, reverse-transcription polymerase chain reaction (RT-PCR), and fluorescence of ZYMVeGFP at 30 dpi.

Viral detection by DAS-ELISA. Young leaves were collected at $30 \mathrm{dpi}$. Extraction buffer $(1: 10 \mathrm{w} / \mathrm{v})$ was added to the leaves, which were then homogenized. DAS-ELISA was performed to detect the virus with a specific commercial polyclonal antibody (Adgen, Leamington Spa, UK) according to the manufacturer's instructions. The results were regarded as positive when the ratio of (tested sample-blank)/(negative control-blank) was $\geq 3$ (Chewachong et al., 2015).

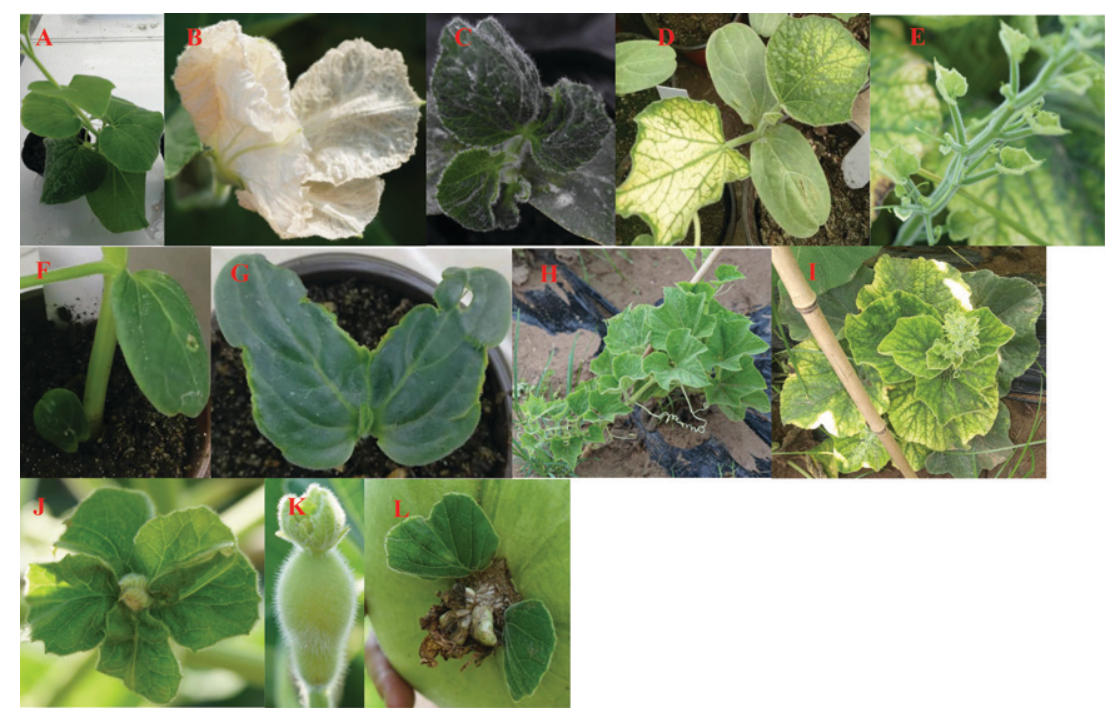

Fig. 1. Examples of morphological mutants observed in the bottle gourd $\mathrm{M}_{2}$ population grown in the greenhouse and the field. Leaves and flowers of wild type (A and B). Different shapes, colors, and leaf sizes $(\mathbf{C}-\mathbf{E})$. Mutated cotyledons $(\mathbf{F}$ and $\mathbf{G})$. Dwarf or semi-dwarf plants with compact architecture ( $\mathbf{H}$ and $\mathbf{I})$. Variations in $\mathbf{M}_{2}$ flowers, mainly nonpetal phenotypes ( $\left.\mathbf{J}-\mathbf{L}\right)$.
Viral detection by RT-PCR. Total RNA was extracted from the $\mathrm{M}_{3}$ and $\mathrm{M}_{4}$ plants. Firststrand cDNA was synthesized from $2 \mu \mathrm{g}$ of total RNA using a Reverse First Strand cDNA Synthesis Kit (Tiangen Biotech, Beijing, China). The primers $5^{\prime}$-TCGTTGCAACCGGAAATTC-3' (forward) and 5'-GCCAACTCTGTAATGCTTC-3' (reverse) were designed from the ZYMV genome sequence. PCR was performed using these primers to detect the virus with an initial incubation at $95^{\circ} \mathrm{C}$ for $5 \mathrm{~min}, 38$ cycles of $95^{\circ} \mathrm{C}$ for $30 \mathrm{~s}, 60^{\circ} \mathrm{C}$ for $30 \mathrm{~s}$, and $72^{\circ} \mathrm{C}$ for $90 \mathrm{~s}$, and a final 5 -min extension at $72^{\circ} \mathrm{C}$. The PCR products were detected by $1 \%$ agarose gel electrophoresis.

Observation of ZYMV-eGFP fluorescence. New leaves were collected to observe GFP fluorescence by confocal microscopy (Leica TCS SP5; Leica Camera AG, Wetzlar, Germany) at 30 dpi. For simultaneous imaging, GFP fluorescence was excited at the 488- $\mathrm{nm}$ laser line. The detection spectrum range was 500 to $587 \mathrm{~nm}$.

\section{Results}

Phenotyping the mutagenized population. To produce $\mathrm{M}_{3}$ seed stocks, 10 to 20 seeds each of the $364 \mathrm{M}_{2}$ families were sown in a nursery and grown to fruit maturity in an open field; then, the $\mathrm{M}_{3}$ seeds were harvested from individual $\mathrm{M}_{2}$ plants. As a result, $2444 \mathrm{M}_{3}$ lines from $303 \mathrm{M}_{2}$ families were collected; however, $61 \mathrm{M}_{2}$ families died during growth or did not produce $\mathrm{M}_{3}$ seeds. At least 10 plants per $\mathrm{M}_{2}$ family were scored for visual phenotype changes in seedlings, flowers, and fruit at key development stages from germination until fruit maturation. Compared with untreated plants, $\approx 4.6 \%$ of the $\mathrm{M}_{2}$ families showed morphological changes, including leaves of different shapes, colors, and sizes, mutated

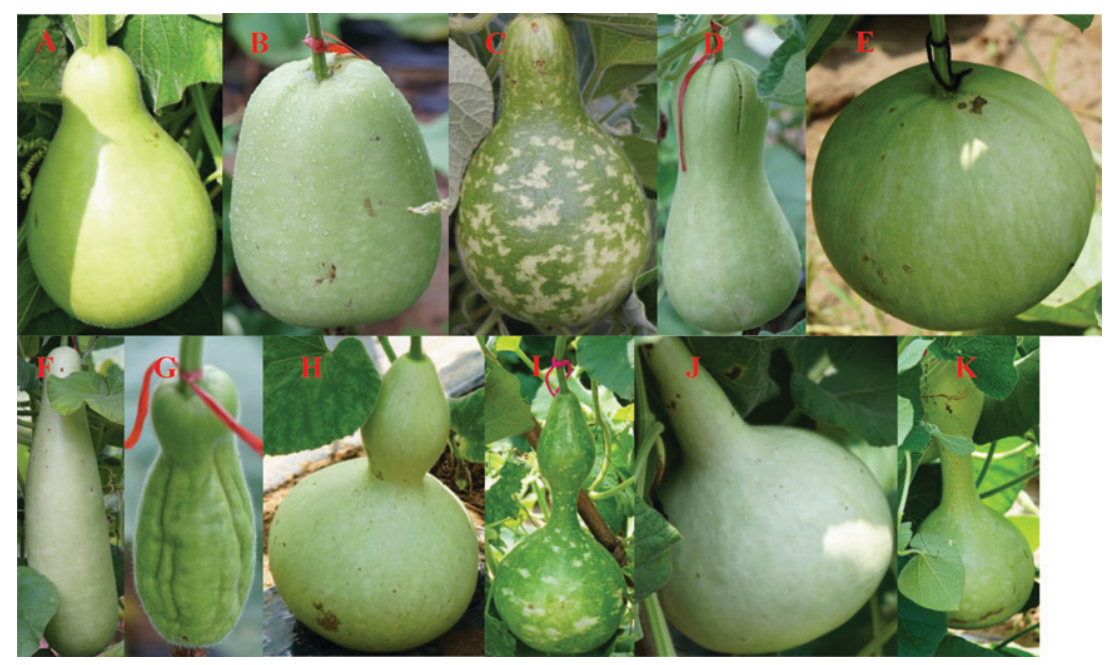

Fig. 2. Diverse shapes and colors of $\mathrm{M}_{2}$ fruits grown in the field. (A) Wild type. (B-K) Variants. (H-K) Observations of one $\mathrm{M}_{2}$ family. 
cotyledons, and dwarfing (Fig. 1A and C-I). Flower variation, mainly in the nonpetal flowers, occurred in 3\% of the $\mathrm{M}_{2}$ families (Fig. 1B and $\mathrm{J}-\mathrm{L}$ ). More than $3.9 \%$ of the $\mathrm{M}_{2}$ families exhibited variation in fruit shape and color (Fig. 2). Overall, $11 \%$ of the $M_{2}$ families showed at least one visible mutant trait.

Additionally, $38 \mathrm{M}_{2}$ families showed no viral symptoms with natural infection, whereas in other M2 families at least one plant displayed viral symptoms. The infected virus was confirmed using RT-PCR (Supplemental Fig. 1), including, but not limited to, ZYMV, watermelon mosaic virus (WMV), cucumber green mottle mosaic virus (CGMMV), and squash mosaic virus (SqMV).

To screen for resistance to ZYMV, 106 $\mathrm{M}_{3}$ lines were selected, including 10 lines from $10 \mathrm{M}_{2}$ families with no viral symptoms in the open field, six lines from five $\mathrm{M}_{2}$ families with mutated flowers or fruits, and five lines from three $\mathrm{M}_{2}$ families with dwarfing. The other lines were from $\mathrm{M}_{2}$ families with normal visual phenotypes (Table 1).

Primary screening. During this test, a total of 106 M3 lines were inoculated mechanically and screened. Plants were classified as susceptible depending on foliar symptoms and the ELISA results at 30 dpi. At $10 \mathrm{dpi}$, mosaic symptoms were observed on the wild type and some lines. By 30 dpi, 29 lines showed viral symptoms that ranged from very mild to severe mottled mosaic, yellowing, chlorosis, and chlorotic or necrotic spots, whereas severe yellowing mosaic with chlorotic spots was observed on the wild type (Fig. 3). The DAS-ELISA confirmed the presence of ZYMV virus in the 29 symptomatic lines. No obvious viral symptoms were observed in the other 77 lines.

Retest. The retest of 77 asymptomatic lines and the wild type through mechanical inoculation showed that there were escapes during primary screening. Forty-four lines were identified as resistant during primary screening, but they were susceptible according to the retest at 30 dpi. Their susceptibilities were also determined by DAS-ELISA or RT-PCR. Two lines (172-3 and 338-12) did not show systemic symptoms at $30 \mathrm{dpi}$; they either expressed symptoms solely on the initial leaves or expressed no clear symptoms, although the virus was detected in young systemic leaves. This suggested that the two lines recovered from the infection.

Third test. To decrease the possibility of escapes, during the third test, an infectious clone of ZYMV carrying eGFP was used to inoculate the wild type and 33 lines that were asymptomatic during the retest. Again, all inoculated wild-type plants (three replicates) showed viral symptoms at $10 \mathrm{dpi}$ and subsequently developed severe yellowing mosaic. Seventeen lines showed viral symptoms at 30 dpi and were confirmed to be susceptible by positive ELISA reactions and strong fluorescence signals. This suggested that there were also escapes during the retest study. Of the remaining 16 symptomless lines, weak fluorescence signals were detected only in vein regions in seven lines, but the ELISA results were negative; therefore, they were
Table $1 . \mathrm{M}_{2}$ phenotypes for tested $\mathrm{M}_{3}$ lines

\begin{tabular}{llc}
\hline No. of tested $\mathrm{M}_{3}$ lines & \multicolumn{1}{c}{ Notes of their $\mathrm{M}_{2}$ families } & No. of resistant lines \\
\hline 10 & No viral symptoms in open field & 1 \\
4 & With mutated flowers & 0 \\
2 & With changed fruit shape & 0 \\
2 & With dwarfing & 1 \\
2 & With deformed leaves & 2 \\
1 & With yellowing leaves & 0 \\
85 & With visual normal phenotypes & 5 \\
Total: 106 & & 9 \\
\hline
\end{tabular}

considered moderately resistant. Ultimately, nine lines showed resistance to ZYMV for seven replicates during the three tests based on the negative ELISA results and the fluorescence signal (Table 2; Fig. 4).

Of these resistant $\mathrm{M}_{3}$ lines, 177-8 was from an $\mathrm{M}_{2}$ family that had no viral symptoms when growing in the open field. The $\mathrm{M}_{2}$ families of 163-3 and 178-6 had deformed leaves, and line 008-6 was a dwarf. The phenotypes suggested that these lines had undergone additional genetic changes with EMS exposure. The other lines were morphologically similar to the wild type and fruit phenotypes.

Developed resistant line. An inbred $\mathrm{M}_{4}$ line of 177-8 was developed and its resistance stability was tested in growth chambers by mechanical inoculation. A total of 39 inoculated plants of this line were asymptomatic (Fig. 5) and negative for ZYMV according to ELISA and PCR test results, which were consistent with those of the $\mathrm{M}_{3}$ line. No susceptible plants segregated during $\mathrm{M}_{4}$ generation suggested that 177-8 line had stable resistance to ZYMV.

\section{Discussion}

Successful mutation breeding depends on the methods used, effective screening techniques, and the populations grown in $\mathrm{M}_{1}$ and successive generations (Toker et al., 2007). For bottle gourd mutagenesis, the EMS concentrations were higher than those used for other cucurbits (González et al., 2011; VicenteDólera et al., 2014). This led to a high proportion $(\approx 63 \%)$ of seedless fruit, which resulted in a small $\mathrm{M}_{2}$ population. In C. pepo, $621 \mathrm{M}_{3}$ families were obtained when using $40 \mathrm{~mm}$ EMS, whereas only 95 were obtained with $80 \mathrm{~mm}$ EMS (Vicente-Dólera et al., 2014). However, the mutation density increases with the EMS concentration, with more multiple

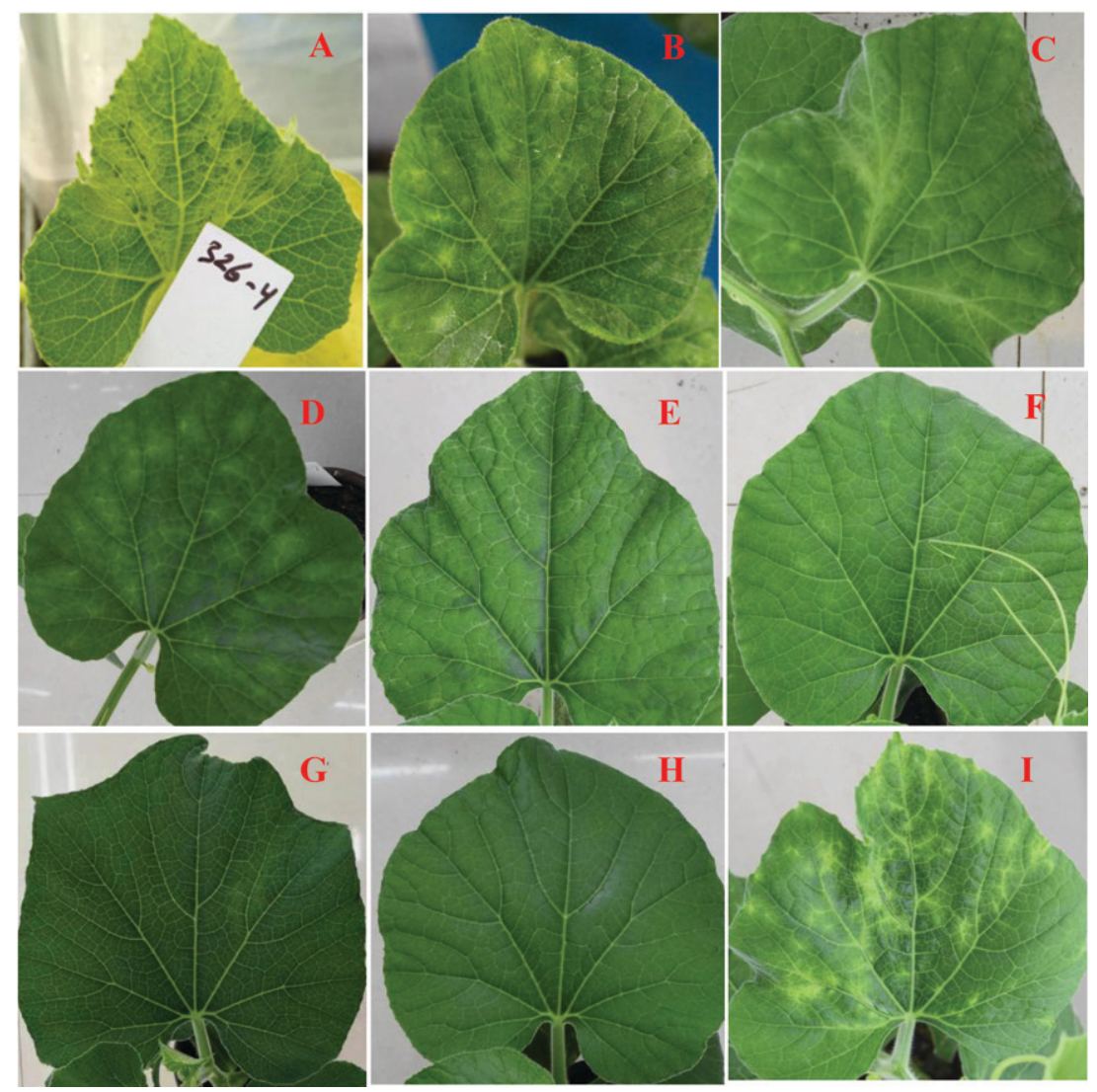

Fig. 3. The expression of viral symptoms on some different lines at $30 \mathrm{~d}$ postinoculation (dpi) with zucchini yellow mosaic virus (ZYMV) induced by a mechanical method. (A and B) Severe yellowing mosaic with chlorotic spots. (C and D) Severe mottled mosaic. (E and F) Mild mosaic. (G) Very mild mottled chlorosis. (H) No symptoms. (I) Severe yellowing mosaic with chlorotic spots on wild type. 
Table 2. Results of the third test after inoculation with the infectious clone of zucchini yellow mosaic virus (ZYMV) enhanced green fluorescent protein (eGFP).

\begin{tabular}{|c|c|c|c|c|}
\hline \multirow[b]{2}{*}{ Line } & \multicolumn{3}{|c|}{ Third test at $30 \mathrm{dpi}$} & \multirow[b]{2}{*}{ Type of resistance } \\
\hline & Symptoms & ELISA & Fluorescence & \\
\hline$\overline{008-6}$ & NS & - & - & R \\
\hline $010-5$ & NS & - & - & $\mathrm{R}$ \\
\hline $078-8$ & NS & - & - & $\mathrm{R}$ \\
\hline $163-3$ & NS & - & - & $\mathrm{R}$ \\
\hline $177-8$ & NS & - & - & $\mathrm{R}$ \\
\hline $178-6$ & NS & - & - & $\mathrm{R}$ \\
\hline $196-13$ & NS & - & - & $\mathrm{R}$ \\
\hline $410-2$ & NS & - & - & $\mathrm{R}$ \\
\hline $422-3$ & NS & - & - & $\mathrm{R}$ \\
\hline 095-1 & NS & - & + & MR \\
\hline $096-6$ & NS & - & + & MR \\
\hline $124-7$ & NS & - & + & MR \\
\hline $253-8$ & NS & - & + & MR \\
\hline $255-3$ & NS & - & + & MR \\
\hline $286-9$ & NS & - & + & MR \\
\hline $337-5$ & NS & - & + & MR \\
\hline $148-3$ & VM.MCH & + & ++ & $\mathrm{S}$ \\
\hline $203-2$ & VM.MCH & + & ++ & $\mathrm{S}$ \\
\hline $331-3$ & VM.MCH & + & ++ & $\mathrm{S}$ \\
\hline 016-13 & M.MCH & + & ++ & $\mathrm{S}$ \\
\hline $105-5$ & M.MCH & + & ++ & $\mathrm{S}$ \\
\hline $130-2$ & M.MM & + & ++ & $\mathrm{S}$ \\
\hline $163-5$ & M.MCH & + & ++ & $\mathrm{S}$ \\
\hline $177-1$ & M.MM & + & ++ & $\mathrm{S}$ \\
\hline $249-6$ & M.MCH & + & ++ & $\mathrm{S}$ \\
\hline $294-6$ & M.MCH & + & ++ & $\mathrm{S}$ \\
\hline $302-11$ & M.MCH & + & ++ & $\mathrm{S}$ \\
\hline $312-6$ & M.MCH & + & ++ & $\mathrm{S}$ \\
\hline $316-8$ & M.MM & + & ++ & $\mathrm{S}$ \\
\hline $325-10$ & M.MCH & + & ++ & $\mathrm{S}$ \\
\hline $329-5$ & M.MCH & + & ++ & $\mathrm{S}$ \\
\hline $038-7$ & S.YM & + & ++ & $\mathrm{S}$ \\
\hline $189-4$ & S.YM & + & ++ & $\mathrm{S}$ \\
\hline $\mathrm{CK}+$ & S.YMCH & + & ++ & $\mathrm{S}$ \\
\hline CK- & $\mathrm{H}$ & - & - & \\
\hline
\end{tabular}

$\mathrm{NS}=$ no symptom; VM.MCH = very mild mottled chlorotic; $\mathrm{M} . \mathrm{MCH}=$ mild mottled chlorotic; $\mathrm{M} . \mathrm{MM}=$ mild mottled mosaic; $\mathrm{S} . \mathrm{YM}=$ severe yellowing mosaic; $\mathrm{S} . \mathrm{YMCH}=$ severe yellowing mosaic with chlorotic spots; $\mathrm{R}=$ resistant; $\mathrm{MR}=$ moderately resistant; $\mathrm{S}=$ susceptible; $\mathrm{H}=$ healthy; $\mathrm{CK}+$ and $\mathrm{CK}-=$ positive and negative controls for WT; $-=$ negative reaction; $+/++=$ the positive reaction of ELISA and fluorescence, the number of " +" represented roughly the signal intensity of fluorescence.

mutations (Martin et al., 2009; Minoia et al., 2010). During this study, three identified lines (163-3, 178-6, and 008-7) had multiple phenotypes combining dwarfing or deformed leaves with resistance; this might have been because of the high EMS dose. For screening, agroinfiltration was used during the third test to ensure that sufficient virus entered the plants because escape often occurs with low inoculum densities or heterogeneous environmental conditions (Guner et al., 2019).

Mutation breeding induces recessive genes more often than dominant genes. Potyvirus resistance is often conferred by recessive genes (Amano et al., 2013; Ling et al., 2009; Wang and Krishnaswamy, 2012). Many reports have suggested that mutation breeding is an efficient way to produce virus resistance with EMS treatment in plants (Manzila and Priyatno, 2020; Souza et al., 2017; Yamanaka et al., 2002). In general, mutations are beneficial with very low frequencies, but the mutation rate varies among species, traits, and even varieties of same the species (Toker et al., 2007; Wani et al., 2014). For tomato, 39\% of $\mathrm{M}_{2}$ plants showed at least one visible mutant trait, and $37 \%$ of these lines showed multiple phenotypes (Minoia et al., 2010). During our study, $11 \%$ of $\mathrm{M}_{2}$ plants had visible mutant traits and $8 \%$ were resistant to ZYMV. These results show the high efficiency of EMS for inducing resistance to ZYMV. Ling and Levi (2007) reported that out of 190 bottle gourd germplasms, 36 accessions had complete resistance to ZYMV and 64 had incomplete resistance. Perhaps the bottle gourd has many potential resistance genes. The lines identified in this report are valuable for further exploration of resistance genes.

The bottle gourd is the preferred rootstock for watermelon because it controls soil-borne diseases and has no effect on fruit quality (Davis et al., 2008; Fidan et al., 2016). Despite a long cultivation history, there are no virusresistant bottle gourd cultivars. The resistant lines identified during this study may be useful as watermelon rootstock or valuable for breeding, exploring resistance genes, and characterizing traits.

\section{Literature Cited}

Amano, M., A. Mochizuki, Y. Kawagoe, K. Iwahori, K. Niwa, J. Svoboda, T. Maeda, and Y. Imura. 2013. High-resolution mapping of zym, a recessive gene for Zucchini yellow mosaic virus resistance in cucumber. TAG. Theoretical and applied genetics. Theoretische und angewandte Genetik 126:2983-2993, doi: https:// doi.org/10.1007/s00122-013-2187-5.

Boualem, A., S. Fleurier, C. Troadec, P. Audigier, A.P. Kumar, M. Chatterjee, A.A. Alsadon, M.T. Sadder, M.A. Wahb-Allah, A.A. AlDoss, and A. Bendahmane. 2014. Development of a Cucumis sativus TILLinG platform for forward and reverse genetics. PLoS One 9:e97963, doi: https://doi.org/10.1371/journal. pone. 0097963.

Chewachong, G.M., S.A. Miller, J.J. Blakeslee, D.M. Francis, T.J. Morris, and F. Qu. 2015. Generation of an attenuated, cross-protective pepino mosaic virus variant through alignmentguided mutagenesis of the viral capsid protein. Phytopathology 105:126-134, doi: https://doi. org/10.1094/PHYTO-01-14-0018-R.

Colla, G., Y. Rouphael, C. Leonardi, and Z.L. Bie. 2010. Role of grafting in vegetable crops grown under saline conditions. Scientia Hort. 127:147155, doi: https://doi.org/10.1016/j.scienta.2010. 08.004

Dahmani-Mardas, F., C. Troadec, A. Boualem, S. Leveque, A.A. Alsadon, A.A. Aldoss, C. Dogimont, and A. Bendahmane. 2010. Engineering melon plants with improved fruit shelf life using the TILLING approach. PLoS One 5:e15776, doi: https://doi.org/10.1371/journal.pone.0015776.

Davis, A.R., P. Perkins-Veazie, Y. Sakata, S. López-Galarza, J.V. Maroto, S.-G. Lee, Y.-C. Huh, Z. Sun, A. Miguel, S.R. King, R. Cohen, and J.-M. Lee. 2008. Cucurbit grafting. Crit. Rev. Plant Sci. 27:50-74, doi: https://doi.org/ 10.1080/07352680802053940.

Desbiez, C. and H. Lecoq. 1997. Zucchini yellow mosaic virus. Plant Pathol. 46:809-829, doi: https:// doi.org/10.1046/j.1365-3059.1997.d01-87.x.

Duprat, A., C. Caranta, F. Revers, B. Menand, K.S Browning, and C. Robaglia. 2002. The Arabidopsis eukaryotic initiation factor (iso)4E is dispensable for plant growth but required for susceptibility to potyviruses. Plant J. 32:927-934, doi: https://doi.org/10.1046/j.1365-313X.2002. 01481.x.

Fidan, H., N. Denli, H. Yetisir, P.K. Öztürk, and C. Nacar. 2016. Open-field survey of Turkish bottle gourd germplasm reaction to virus disease, $\mathrm{p}$. 283-287. The XIth EUCARPIA Meeting on Genetics and Breeding of Cucurbitaceae.

Gaion, L.A., L.T. Braz, and R.F. Carvalho. 2017. Grafting in vegetable crops: a great technique for agriculture. Intl. J. Veg. Sci. 24:85-102, doi: https://doi.org/10.1080/19315260.2017.1357062.

Gal-On, A. 2000. A point mutation in the FRNK motif of the potyvirus helper component-protease gene alters symptom expression in cucurbits and elicits protection against the severe homologous virus. Phytopathology 90:467-473, doi: https://doi.org/ 10.1094/PHYTO.2000.90.5.467.

González, M., M. Xu, C. Esteras, C. Roig, A.J. Monforte, C. Troadec, M. Pujol, F. Nuez, A. Bendahmane, J. Garcia-Mas, and B. Pico. 2011. Towards a TILLING platform for functional genomics in Piel de Sapo melons. BMC Res. Notes 4:289, doi: https://doi.org/10.1186/17560500-4-289.

Guner, N., Z. Pesic-VanEsbroeck, L.A. Rivera-Burgos, and T.C. Wehner. 2019. Screening for resistance to zucchini yellow mosaic virus in the watermelon germplasm. HortScience 54:206211, doi: https://doi.org/10.21273/hortsci13325-18. Guner, N., L.A. Rivera-Burgos, and T.C. Wehner. 2018. Inheritance of resistance to zucchini yellow mosaic virus in watermelon. HortScience 


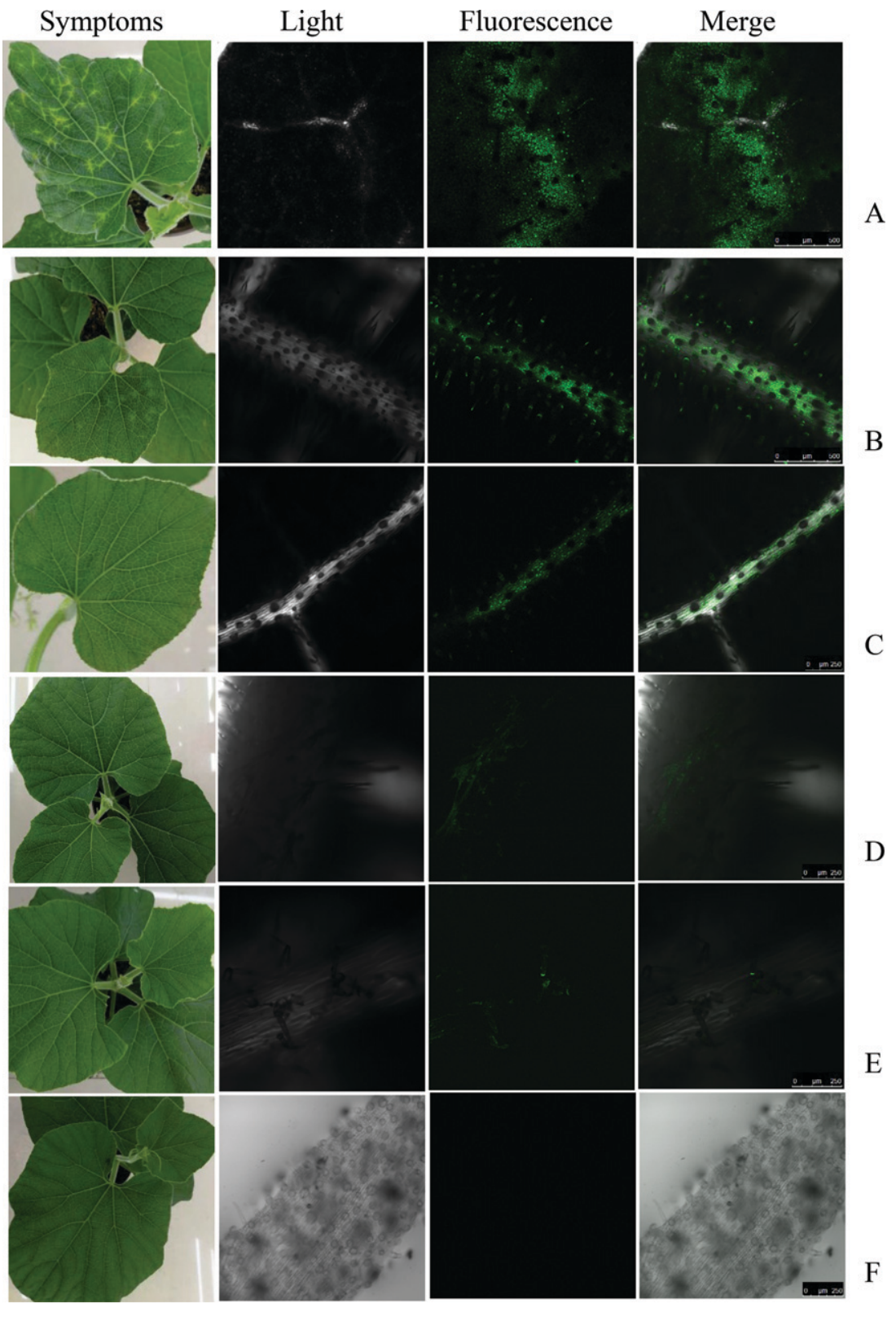

Fig. 4. Detection of the GFP signal in leaves at 30 dpi with zucchini yellow mosaic virus (ZYMV) enhanced green fluorescent protein (eGFP) by agroinfiltration. The left row suggests the symptoms of detected lines. Strong fluorescence signals are detected in lines with severe symptoms (A; widetype), mild symptoms $(\mathbf{B} ; 177-1)$, and recovery $(\mathbf{C} ; 016-13)$. Weak fluorescence signals are detected in vein regions (D and $\mathbf{E} ; 124-7$ and $253-8$ ) in some symptomless lines. No fluorescence signals are detected in some symptomless lines $(\mathbf{F} ; 010-5)$.
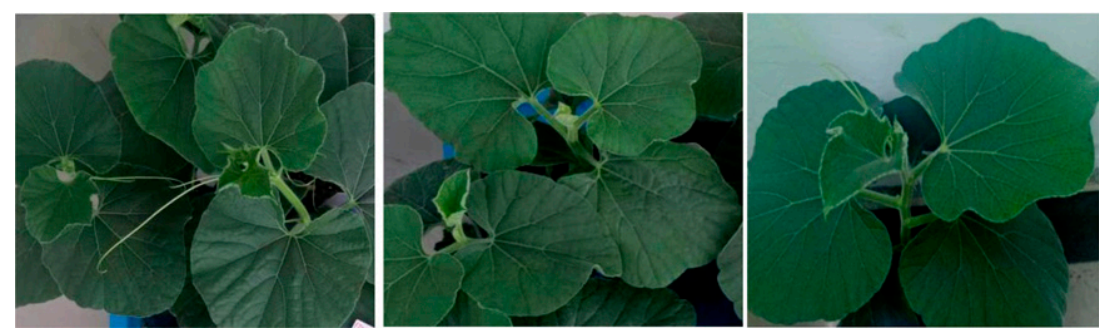

Fig. 5. No symptoms in 177-8 $\mathrm{M}_{4}$ plants at $30 \mathrm{~d}$ postinoculation (dpi) with zucchini yellow mosaic virus (ZYMV) induced by a mechanical method in growth chambers.

53:1115-1118, doi: https://doi.org/10.21273/ Hortsci13169-18.

Kang, B., J. Li, L. Liu, and Q. Gu. 2017. Screening optimal condition of mutagenesis with EMS for bottle gourd (Lagenaria siceraria) seed. Chinese
Cucurbits Veg. 30(2):7-10, 21, doi: https://doi. org/10.16861/j.cnki.zggc.2017.0025.

Lellis, A.D., K.D. Kasschau, S.A. Whitham, and J.C. Carrington. 2002. Loss-of-susceptibility mutants of Arabidopsis thaliana reveal an essential role for eIF(iso)4E during potyvirus infection. Curr. Biol. 12:1046-1051, doi: Pii S0960-9822(02)00898-9.

Ling, K.S., K.R. Harris, J.D. Meyer, A. Levi, N. Guner, T.C. Wehner, A. Bendahmane, and M.J. Havey. 2009. Non-synonymous single nucleotide polymorphisms in the watermelon eIF4E gene are closely associated with resistance to zucchini yellow mosaic virus. Theor. Appl. Genet. 120:191-200, doi: https://doi.org/ 10.1007/s00122-009-1169-0.

Ling, K.S. and A. Levi. 2007. Sources of resistance to zucchini yellow mosaic virus in lagenaria siceraria germplasm. HortScience 42:1124-1126.

Ling, K.S., A. Levi, S. Adkins, C.S. Kousik, G. Miller, R. Hassell, and A.P. Keinath. 2013. Development and field evaluation of multiple virus-resistant bottle gourd (Lagenaria siceraria). Plant Dis. 97:1057-1062, doi: https://doi. org/10.1094/PDIS-07-12-0639-RE.

Liu, L., B. Kang, B. Peng, H. Wu, Y. Su, and Q. Gu. 2020. Construction of ZYMV infectious clone carrying eGFP and its infectivity. Acta Phytopathol. Sinica (Online), doi: https://doi. org/10.13926/j.cnki.apps.000539.

Manzila, I. and T.P. Priyatno. 2020. Genetic variations of EMS-induced chili peppers (Capsicum annuит) cv. Gelora generate geminivirus resistant mutant lines. IOP Conf. Ser. Earth Environ. Sci. 482:012031, doi: https://doi.org/ 10.1088/1755-1315/482/1/012031.

Martin, B., M. Ramiro, J.M. Martinez-Zapater, and C. Alonso-Blanco. 2009. A high-density collection of EMS-induced mutations for TILLING in Landsberg erecta genetic background of Arabidopsis. BMC Plant Biol. 9:147, doi: https://doi.org/10.1186/1471-2229-9-147.

Minoia, S., A. Petrozza, O. D’Onofrio, F. Piron, G. Mosca, G. Sozio, F. Cellini, A. Bendahmane, and F. Carriero. 2010. A new mutant genetic resource for tomato crop improvement by TILLING technology. BMC Res. Notes 3:69, doi: https://doi.org/10.1186/1756-0500-3-69.

Nagendran, K., S. Mohankumar, R. Aravintharaj, C.G. Balaji, S.K. Manoranjitham, A.K. Singh, A.B. Rai, B. Singh, and G. Karthikeyan. 2017. The occurrence and distribution of major viruses infecting cucurbits in Tamil Nadu state, India. Crop Prot. 99:10-16, doi: https://doi.org/ 10.1016/j.cropro.2017.05.006.

Okagaki, R.J., M.G. Neuffer, and S.R. Wessler. 1991. A deletion common to two independently derived waxy mutations of maize. Genetics 128:425-431.

Simmons, H.E., J.P. Dunham, K.E. Zinn, G.P. Munkvold, E.C. Holmes, and A.G. Stephenson. 2013. Zucchini yellow mosaic virus (ZYMV, Potyvirus): Vertical transmission, seed infection and cryptic infections. Virus Res. 176: 259-264, doi: https://doi.org/10.1016/j.virusres. 2013.06.016.

Souza, P.F., F.D. Silva, F.E. Carvalho, J.A. Silveira, I.M. Vasconcelos, and J.T. Oliveira 2017. Photosynthetic and biochemical mechanisms of an EMS-mutagenized cowpea associated with its resistance to cowpea severe mosaic virus. Plant Cell Rep. 36:219-234, doi: https://doi.org/10.1007/s00299-016-2074-z.

Svoboda, J., L. Leisova-Svobodova, and M. Amano. 2013. Evaluation of selected cucurbitaceous vegetables for resistance to zucchini yellow mosaic virus. Plant Dis. 97:1316-1321, doi: https://doi. org/10.1094/PDIS-11-12-1009-RE.

Toker, C., S.S. Yadav, and I.S. Solanki. 2007. Mutation breeding, p. 209-214. In: S.S. Yadav, D.L. McNeil, and P.C. Stevenson (eds.). Lentil. Springer, Dordrecht, Netherlands, doi: https:// doi.org/10.1007/978-1-4020-6313-8_13. 
Vicente-Dólera, N., C. Troadec, M. Moya, M. del Rio-Celestino, T. Pomares-Viciana, A. Bendahmane, B. Pico, B. Roman, and P. Gomez. 2014. First TILLING platform in Cucurbita pepo: A new mutant resource for gene function and crop improvement. PLoS One 9:e112743, doi: https://doi.org/10.1371/journal.pone.0112 743.

Wang, A.M. and S. Krishnaswamy. 2012. Eukaryotic translation initiation factor 4E-mediated recessive resistance to plant viruses and its utility in crop improvement. Mol. Plant Pathol.
13:795-803, doi: https://doi.org/10.1111/j.13 64-3703.2012.00791.x.

Wang, H.L., D. Gonsalves, R. Provvidenti, and H.L. Lecoq. 1991. Effectiveness of cross protection by a mild strain of zucchini yellow mosaic virus in cucumber, melon, and squash. Plant Dis. 75:203-207.

Wani, M.R., M.I. Kozgar, N. Tomlekova, S. Khan, A.G. Kazi, S.A. Sheikh, and P. Ahmad. 2014. Mutation breeding: a novel technique for genetic improvement of pulse crops particularly chickpea (Cicer arietinum L.), p.
217-248. In: P. Ahmad, M. Wani, M. Azooz, and L.S. Phan Tran (eds.). Improvement of crops in the era of climatic changes. Springer, New York, NY, doi: https://doi.org/10.1007/ 978-1-4614-8824-8_9.

Yamanaka, T., T. Imai, R. Satoh, A. Kawashima, M. Takahashi, K. Tomita, K. Kubota, T. Meshi, S. Naito, and M. Ishikawa. 2002. Complete inhibition of tobamovirus multiplication by simultaneous mutations in two homologous host genes. J. Virol. 76:2491-2497, doi: https:// doi.org/10.1128/Jvi.76.5.2491-2497.2002. 


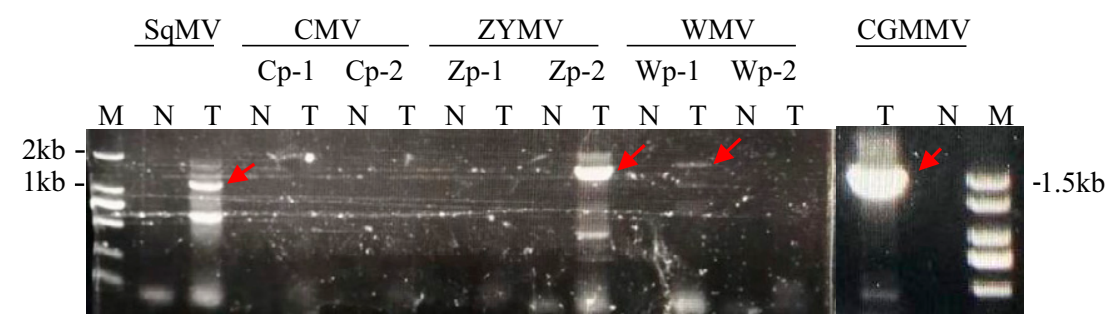

Supplemental Fig. 1. The results of one-step reverse-transcription polymerase chain reaction (RT-PCR) to detect squash mosaic virus (SqMV), cucumber mosaic virus CMV, zucchini yellow mosaic virus (ZYMV), watermelon mosaic virus (WMV), and cucumber green mottle mosaic virus (CGMMV) in $\mathrm{M}_{2}$ plants in the field. $\mathrm{T}=$ tested sample comprising a mixture of RNAs from $14 \mathrm{M}_{2}$ plants with virus-like symptoms in the field; $\mathrm{N}=$ negative sample of a healthy plant; $\mathrm{M}=$ marker. The middle line with $\mathrm{Cp}-1, \mathrm{Cp}-2$, etc., indicates the specific primers for viruses. Except for SqMV and CGMMV, other viruses were detected using two different specific pairs of primers. The bands marked with a red arrow indicate positive results. 